\title{
Olga Lebedeva ( Madame Gülnar): A Russian Orientalist and Translator Enchants the Ottomans
}

This work was supported by Scientific Research Projects Coordination Unit of Istanbul University. Project number 21043.

TÜRKAN OLCAY

Istanbul University

\section{AbStraCt}

Based on the studying of a number of archive and scientific literature sources, the article attempts a research of life and works of the first Russian female orientalist Olga Sergeevna Lebedeva. Under the pseudonym 'Gülnar', she was one of the first to introduce the Turkish reading public to the treasures of Russian literature, thus making an invaluable contribution to Turkish-Russian literary connections at the end of the nineteenth century. A special place in the article is devoted to Olga Lebedeva's translations and literary critical studies in the Ottoman Empire in 1890s and also interrelationship between her and the prominent Ottoman writer and publisher Ahmet Mithat Efendi.

\section{Ahmet Mithat Meets Madame Gülnar}

On the third of September 1889, at the reception in honor of the delegates of the Eighth Congress of Orientalists in Stockholm (hosted by Countess Landsberg'), the Russian Consul-General introduced a 'no more than forty year old woman of medium height' to the official representative of the Ottoman Porte and member of the Turkish delegation, the writer and publisher Ahmet Mithat Efendi (1844-1912) (Figure 1) with the words 'The Madame is a Russian aristocrat and polyglot who speaks several languages, including Ottoman Turkish, wishes to meet you.'2

The lady called herself Gülnar and held out her visiting card. In clear Ottoman she added that following his speech at the opening of the Congress her desire to meet him increased during the day's conference after his lecture in French on Eastern women. Ahmet Mithat's attention was drawn both to the

\footnotetext{
1 Wife of Count Landsberg, the head of the organizing committee at the Congress.

2 Ahmet Mithat Efendi, Avrupa'da Bir Cevelan [Tour of Europe], translit. of Ottoman Turkish by Arzu Pala, reprint (Istanbul: Dergah Yayınlar1, 2015), p. 193.
} 
name of this lady and by her melodious Ottoman speech and they struck up a friendly conversation. It turned out that:

Apart from Russian, her mother tongue, the lady also spoke French, German, English and Greek fluently, had a good knowledge of Italian, Arabic and Persian languages [...] and she was also very talented at playing the piano and painting. ${ }^{3}$

Ahmet Mithat would be so very impressed with his new acquaintance that he spent the rest of the time outside of the conference with her and her colleague from Russia Prof. Joseph Gottwald. Madame Gülnar spoke to the Turkish educator about the greatness of Russian literature and when he asked 'Is it really so great?' she gave him a manuscript of her own translation into Ottoman of Leo Tolstoy's short story Ilyas. Amongst those pages of translation, that she had put on the table, Mithat Efendi noticed by chance the envelope with her real name preceded by the title 'Excellency'. Having received from him the promise that he would for the time being not divulge this information to his associates - as Mithat had informed her about his plans to publish his European travel notes ${ }^{4}-$ she informed him that her actual name was Olga Sergeevna Lebedeva.

\section{But Who Are You Really, Madame Gülnar?}

Olga Sergeevna Lebedeva (1854-after 1912) was the first Russian female orientalist. She was the founder in St Petersburg of the Society of Oriental Studies, a researcher of the place and role of women in Muslim society, a translator and mother to six children. ${ }^{5}$

Notwithstanding all her social and educational activities, starting from the last quarter of the nineteenth century and until the first ten years of the twentieth century, information about her life and work is very fragmentary. The most illuminating of all are the years of her stay and work in the Ottoman Empire

\footnotetext{
${ }^{3}$ Mithat, pp. 194-95.

${ }^{4}$ Ahmet Mithat will stand by his words: throughout the travelogue, her real name is discretly hidden.

${ }^{5}$ Ömer Faruk Akün, 'Gülnar Khanum' in Islâm Ansiklopedisi [Encyclopedia of Islam] 44 vols, ed. by Prof. Ahmet Topaloğlu (Istanbul: TDV, 1988-2013), XIV (1996), 243-48 (p. 243).
} 
which to a large extent were described by the travelogue and letters of Ahmet Mithat Efendi, dating from the last ten years of the nineteenth century. From these we know that she was an aristocrat of noble title and wife of the Mayor of Kazan who also had a noble title. ${ }^{6}$

From the documents and materials about Kazan Mayors we learn that the name of Olga Sergeevna's husband was Alexander Alexandrovich Lebedev (1843-1910) and that he was an Active State Counselor and the Mayor of Kazan from 1883 to 1886 and again from 1899 to September 1903. ${ }^{7}$ From this same source we learn that Olga Sergeevna's maiden name was Barshcheva and that the spouses had three children: Alexander born in 1880, Olga born in 1881, and Michael born in $1886 .{ }^{8}$ Information confirming family links as well as findings about the children were obtained from the Lebedevs' family tree.

The marriage of Olga Sergeevna to Alexander Lebedev was her second one. Thus, including the children from the first marriage Lebedeva was a mother of six. ${ }^{9}$

According to Ahmet Mithat Efendi’s memoirs Olga Sergeevna grew up at a large mansion near Kazan where a great number of Tatars worked in the fields and the estate. Thanks to her direct communication with them she got to know their Eastern customs and manners. She learned conversational Tatar from them which, at that time, was full of Arabic and Persian loan words. ${ }^{10}$

The name of Olga Lebedeva was first heard in public at Orientalist circles in 1886 when her translation from the Tatar to Russian of the book Qabus Nameh [Book of Qabus] written by an Iranian ruler Keikavus (Unsur al-Maali) was published. ${ }^{11}$ Her chief mentor this time was a famous Tatar educator and 'father' of the modern literary language Kaium Nasyri (1825-1902) who actually translated this literary jewel of Persian literature from the original language into Tatar in 1882. Lebedeva took lessons of Arabic, Persian and Turkish languages from him. Together they attended sessions of the Archaeological, historical and ethnographic society at Kazan University. Amongst the members of this society were a famous scholar and teacher of Eastern languages at Kazan University Shigabutdin Mardzhani, a scholar Mohammed Ali Makhmudov, a writer Abdrakhman Ilyasi and other activists of Tatar education and culture with whom Olga

\footnotetext{
${ }^{6}$ Mithat, p. 194.

${ }^{7}$ Dostoini pamyati potomkov. Gorodskie golovy Kazani 1767-1917 gg. [Worthy of the memory of the descendants. City Heads of Kazan in 17671917], ed. by L. V. Gorohova (Kazan: Gasyr, 2002), p. 225.

8 Ibid., p. 229.

9 'Gülnar Hanım namı diğer Olga de Lebedeff ['Gülnar Khanum or so-called Olga de Lebedeff], Serveti Fünûn [Treasury of Knowledge], 20 June 1307 [2 July 1891], pp. 170-73 (p.173).

${ }^{10}$ Kamil Yazg1ç, Ahmet Mithat Efendi: Hayatı ve Hatıralar [Ahmet Mithat Efendi: His Life and Memoirs], (Istanbul: Tan Matbaası, 1940), p. 60 .

11 Qabus Nameh, trans. by O. S. Lebedeva (Kazan: Typografia Imperatorskogo Universiteta, 1886).
} 
Sergeevna was in close contact. ${ }^{12}$ Besides, she also attended lectures on the language, history and culture of Turkish and other Islamic peoples at the Kazan University. ${ }^{13}$

Olga Sergeevna mastered the Eastern culture and absorbed the spiritual values of the Turks to such extent that she chose a literary pseudonym 'Gülnar' for herself which in Farsi means 'pomegranate flower'. It was this name that she introduced herself with to Ahmet Mithat in 1889 at the Congress of Orientalists in Stockholm. Subsequently, Olga Lebedeva signed her published in Istanbul translations using 'Madame Gülnar', 'Madame Gülnar Olga Dölebedeva' and 'Olga de Lebedeff' while letters to her Turkish friends were simply signed 'Gülnar'. In her French works, her family name is usually spelt 'de Lebedeff or 'de Lébédew’

\section{JOINT TRAVELS IN EUROPE}

At the end of the Congress whose closing sessions were transferred to the Norwegian capital Oslo ${ }^{14}$, Ahmet Mithat offered Olga Lebedeva and Prof. Joseph Gottwald and also his accompanying daughter Mme Krelemberg and the Dr Boris Janpolsky to join his train trip to several European capitals and cities. ${ }^{15}$ The proposal was courteously accepted and on 13 September they set off to Copenhagen via Gothenburg and Helsinki. After a couple of days sightseeing Dr Janpolsky left for Belgium but the rest continued on their journey to Berlin. On 19 September, bidding farewell to Prof. Gottwald and his daughter, Ahmet Mithat and Olga Lebedeva set off for Cologne and from there to Paris where they spent twelve days. On the seventh day they were joined in Paris by her mother and son Sasha Lebedev who were on their way the seaside spa resort of Arcachon for the nine-year old's health - it is, by the way, one of the most unique information about her family. On 1 October 1889, Lebedeva, having received an approval from her husband to travel to Nice instead of Arcachon, said goodbye to Mithat Efendi who was continuing his journey through Switzerland and Austria. From the moment on they regularly corresponded. Their acquaintance at the Congress and the friendship made over four-week communication marked the beginning of a joint activity on publication of Russian classical literature in Turkey.

\footnotetext{
12 A. G. Karimullin, 'O. S. Lebedeva - Gulnar khanum', Narody Azii i Afriki [Peoples of Asia and Africa], 3, March (1977), 146-52 (p. 148).

13 Women were granted the right to education at Kazan University in 1905.

${ }^{14}$ Christiania (from 8-11 September 1889).

15 See Carter V. Findley, Ahmet Mithat Efendi Avrupa'da [An Ottoman Occidentalist in Europe: Ahmed Midhat Meets Madame Gülnar, 1889], trans. by Ayşen Anadol (Istanbul: Tarih Vakfi Yurt Yayınları, 1999).
} 
The main topic of their conversations during the congress and their trip was a comparison of East and West; they discussed the differences between the two from the point of view of ethics and culture. They examined the position of Eastern women, their social and family lives. On Eastern questions, Ahmet Mithat was undoubtedly the expert. Conversations also touched upon religion, philosophy and culture, in particular fine arts, music and literature. Sometimes the roles changed - Olga Sergeevna became his mentor. She talked about European art: painters, architecture, theatre, music, and opera. Mithat was amazed at her knowledge in so many areas of culture. Once during a visit to one of the picture galleries he remarked that the picture frames are more impressive than the pictures themselves. However, Olga Sergeevna began to explain to him the value of that particular school of painting. Mithat was staggered by her subtle understanding of Western art and how it combined with a sincere love of Eastern culture and the Ottoman language. Even the everyday Eastern traditions were close to her. For example, she always carried with her a coffee pot and treated her guests with a real Turkish coffee. She liked to wear Turkish costumes at home and to see her children wearing fezzes. She dressed quite strictly in a society, as she said she did not like to see a woman in a dress with a low-cut neckline. It is surprising that she even made remarks about Ahmed Mithat's clothing. For example, as an official delegate from the Ottoman Porte at the Congress on one occasion Ahmet Mithat was unexpectedly invited to a dinner party. Mithat wanted to wear the same clothes that he wore in the street. Olga Sergeevna convinced him that he should return to the hotel and put on his best suit and wear the medals he had been awarded. ${ }^{16}$

During the trip, Lebedeva introduced her travelling companion to Russian culture, in particular Russian literature, and retold him several works. In his travelogue Ahmet Mithat shares:

I derived so much benefit hearing her explain to me the phases of progress travestied by Russian language and literature from the oldest times until today that I turned into a person who had recognized and learnt the Russian nation anew. ${ }^{17}$

Already at that stage, their plans about the necessity to introduce Russian classics to Turkish readers started taking shape.

\footnotetext{
16 Mithat, pp. 213, 218, 237.

17 Ibid., p. 474.
} 
Ahmet Mithat Efendi described his seventy-day trip in Europe, including his work at the Eighth Congress of Orientalists, in detail in his essay called Avrupa'da Bir Cevelan [Tour of Europe] which was published in sections in the newspaper Tercüman-ı Hakikat [Translator of Trutb] established and owned by him. Several months later, Tour of Europe came out as a separate publication in one thousand thirty pages. This book is a key source of information about Olga Lebedeva. Noteworthy is the fact that five hundred ninety six pages of it are occupied by the story of meeting, a four-week cultural program with Lebedeva and personal information about her as a turkologist and a public figure. ${ }^{18}$

Thus, starting from 25 December 1889, before her first visit to the Ottoman Empire, Lebedeva entered the focus of Turkish society's attention as an erudite Russian woman full of great love for the Turks and their culture.

In a number of Russian sources, it is reported that Olga Lebedeva had previously travelled to Istanbul in 1881, that is to say, before her meeting with Ahmet Mithat. In this way, for example, a renowned orientalist Alexander Shifman writes in his work Lev Tolstoy i vostok [Leo Tolstoy and the East]:

Having a thorough plan to translate Russian authors into Turkish, Lebedeva arrived in Constantinople to obtain permission from the Turkish authorities. But here a great disappointment was expecting her: the Turkish government suspected her of being a secret Russian agent and strongly forbade the publication of any of her translations from Pushkin. ${ }^{19}$

In an article 'Lebedeva, Olga Sergeevna (Gulnar Khanum)' in the Biobibliographicheskiy slovar otechestvennih turkologov [Biobibliographical Dictionary of Native Turkologists] it is written that:

The Turkish authorities suspected her works of bearing propaganda for Russian political and religious thinking which became the reason why she was not allowed to publish her translations of Pushkin's work at the time of her first visit in $1881 .^{20}$

\footnotetext{
18 Ibid., pp. 193-789.

${ }_{19}$ A. I. Shifman, Lev Tolstoy i vostok [Leo Tolstoy and the East], 2nd edn. (Moscow: Nauka, 1971), p. 403.

20 A. N. Kononov, 'Olga S. Lebedeva', in Biobibliographicheskiy slovar otechestvennih turkologov: Dooktyabrskiy period [Biobibliographical Dictionary of Native Turkologists: Pre-October period], ed. by Andrei N. Kononov (Moscow: GRVL, 1974), pp. $204-05$.
} 
However, the initial publication of her earlier translations in a widely distributed newspaper in 1890 , then in separate publications, as well as the honorary medal given to her by the Sultan Abdul Hamid II (years of rule 1876-1909) (to be described below), makes this hypothesis very unlikely. Moreover, that in 1880 and in 1881 Olga Sergeevna gave birth to two children. Nevertheless, we cannot disregard her letter sent to Leo Tolstoy on 23 June 1894 from which we learn that 'due to the unusually strict and absurd censorship, the selection of works is very difficult and they had to be restricted to these. ${ }^{21}$

\section{INVITATION, ISTANBUL WORKS, AND WORRIES}

Judging by the local press of the period, the first time Olga Lebedeva arrived in Istanbul via Odessa was on 13 October 1890. This visit took place at the invitation of Ahmet Mithat Efendi. Being a Westerner in his views, Ahmet Mithat was particularly concerned about enhancing the status of women in Turkish society regarding their education, involvement in the social life and world of art, specifically in literature. ${ }^{22}$ In his eyes, Olga Lebedeva represented a model figure for a modern woman. This is why he invited her to Istanbul. On the one hand, his aim was to acquaint her closer with the way of life on an Ottoman estate, with appearance of an Eastern woman and their place in the family and society, to introduce Lebedeva as a role model of a social activist and as a writer for Turkish women novelists and poetesses (in his correspondence with Fatma Aliye ${ }^{23}$ he often set Olga Lebedeva as an example for her). On the other hand, with Lebedeva's help he hoped to introduce Western European circles with Eastern ethics and moral values.

As soon as Olga Sergeevna had arrived, Ahmet Mithat notified everyone in his circle. This is what he wrote to Fatma Aliye:

An outstanding Russian lady, Gülnar Khanum, i.e. Madame de Lebedeff, has just arrived in Istanbul; through her advice I learned an immense amount during my travels in

\footnotetext{
${ }^{21}$ Shifman, p. 404. In 1894, Olga Lebedeva had a correspondance with Leo Tolstoy. In her letters she describes the life in Turkey and shares some working plans. See Shifman, pp. 403-14.

22 See Orhan Okay, Batı Medeniyeti Karşısında Abmet Midhat Efendi [Ahmet Midhat Efendi in the Face of Western Civilization] (Istanbul: MEB, 1975); Hülya Argunşah, Kadın ve Edebiyat. Babasının Kı̨ı Olmak (The Woman and Literature. Being The Daughter of Your Father), (Istanbul: Kesit Yayınlar1, 2016); —_, Kadin ve Edebiyat. Kendini Yazmak. [Women and Literature. Writing Yourself], (Istanbul: Kesit Yayınlar1, 2016).

${ }^{23}$ Fatma Aliye (1862-1936) is the first modern woman novelist in Ottoman literature.
} 
Europe. She is widely read and is fond of Ottoman studies and Islam, and I would like to introduce her to several prominent families. ${ }^{24}$

Lebedeva lived for several weeks at Ahmet Mithat's villa located on the Asian side of Istanbul (in Beykoz area), where she met Mithat's extended family, ${ }^{25}$ then she moved to a recently opened elite hotel De Belle Vue $e^{26}$ in Pera (Figure 2) where she stayed until the middle of May 1891.

During her first seven-month stay in Istanbul Olga Sergeevna undertook active translation work and research. On her arrival here she had brought with her several previously translated works of Alexander Pushkin and Mikhail Lermontov and also an essay about Pushkin. Exactly a week after her arrival they began to be published in parts in Ahmet Mithat's newspaper. ${ }^{27}$ Apart from this, jointly with the editor Ahmet Cevdet, she translated two treaties by the Tatar educator and Imam of the Muslim community in St Petersburg Ataullah Bayazitov (1846-1911).

From the correspondence between Ahmet Mithat and Fatma Aliye we also learn that along with the activity aimed at the reading public in Turkey Lebedeva was preparing for the Ninth Congress of Orientalists in London. Besides studies on Islam and Turkish public life, under Mithat's advisory, she was planning to publish a textbook, an Anthologie orientale [Oriental Anthology] including collections from ancient and modern Persian, Arabic, and Ottoman literature. Original Arabic texts were accompanied by Latin transliteration, a translation and a corresponding explanation.

Knowing the way of life of Turkish women Lebedeva empathized with them entirely. Proof of this becomes apparent in her notes regarding the publication of the book by Baroness Staffe ${ }^{28}$ translated by Ahmet Mithat Miuftiuoglu in 1891 about female beauty and personal care called Tuvalet ve Letaif-i Aza [Cabinet de Toilette].

During her stay in Istanbul Olga Lebedeva further perfected her knowledge of Ottoman and Arabic with the help of the editor Ahmet Cevdet and of Persian with a prominent writer Habib Efendi (Mirza).

In addition, upon Mithat Efendi's recommendation, she worked on translation from Ottoman into

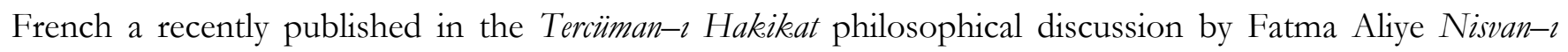

\footnotetext{
${ }^{24}$ Ahmed Midhat Efendi, Faz̨l ve Feylesof Kızım. Fatma Aliye'ye Mektuplar [My Spiritual and Philosopher Daughter. Letters to Fatma Aliye], prep. for publ. by F. S. Inceoğlu and Z. S. Berktaş (Istanbul: Klasik, 2011), p. 57.

25 Yazg1ç, pp. 82-84.

${ }^{26}$ A few months later the hotel will be renamed to Grand Hotel De Londres.

27 Akün, p. 244.

${ }^{28}$ The pseudonym for Blanche Soyer (1843-1911).
} 
Islam [The Women of Islam] which was written in response to popular contemporary works by Western orientalists. The work became the first attempt to unveil the true situation of a woman in society and especially her role in the union of marriage. ${ }^{29}$

Frequent mention of Olga Lebedeva's name in the local press, distribution of information about her activities and also her active contact with both Turkish and foreign elite circles facilitated a speedy growth of her popularity. All this began to be addressed by the European press, too. So, for example, in the section of news about Turkey of the Belgian newspaper L'Opinion, an extensive article was published on Lebedeva, where the emphasis was made on her as a polyglot who mastered ten foreign languages as well as her skills at literary writing, which served to introduce Russian classical literature to Turkish readers. In response to this, on 4 April $1307^{30} / 16$ April1891, deep thanks were expressed in the pages of the newspaper Tercüman-ı Hakikat. ${ }^{31}$

The name of Lebedeva is mentioned also in a few American publications. From the local press we know that to support orphans she wrote in English an article Orphan's Gratitude for an American journal. The article discussed the fact that, compared with the West, in the Islamic world there is better welfare for orphans and poor children. ${ }^{32}$

Completed in a short period, Olga Lebedeva's precious works were presented to the Sultan Abdul Hamid II, who greatly appreciated them - he personally awarded the author with a medal established in 1878 and called Zişan-ı şefkeat [The Order of Compassion] II Degree and a Diploma for services to Oriental studies.

In this regard, in the fifteenth edition of the weekly journal Servet-i Fünun [Treasury of Knowledge] was published a complimentary article about Lebedeva with her photograph and the honorary medal on her chest. $^{33}$ (Figure 3)

\footnotetext{
29 The French translation of Fatma Aliye's the Women of Islam appeared only in 1896 in the Bibliothèque du journal 'Orient' et La Turquie' as Les Femmes musulmanes' par Fathma-Alié, traduit par Mme Olga de Lebedeff (sic) connue sous le pseudonyme de Gülnar-Hanoum, Paris, ed. N. Nicolaides.

${ }^{30}$ Rumi calendar. (From the Tanzimat [Reorganizasion], announced in 1839, the Ottoman Empire adopted the specific calendar named 'Rumi' which is based on the Julian calendar but starting with the year of Muhammad's emigration (Hijra) in 622 AD. The Rumi calendar was officially used by the Republic of Turkey until 1926.)

31 'Gülnar Hanım ve Opinion Gazetesi’ne Lazime-i Teşekkür' [Gülnar Khanum and Necessary Thanks to Opinion Newspaper], Tercüman-ı Hakikat, 4 April 1307 [16 April 1891], p. 1.

32 ‘Bir Yetimin Şükranesi’ ['Orphan’s Gratitude’], Tercüman-ı Hakikat, 7 June 1307 [19 June 1891], pp. 1-2.

33 'Gülnar Hanım namı diğer Olga de Lebedeff' ['Gülnar Khanum or so-called Olga de Lebedeff'], Serveti Fünûn [Treasury of Knowledge], 20 June 1307 [2 July 1891], pp. 170-73.
} 
Levedeva learnt about it on her return to Kazan in the middle of May 1891. As a sign of gratitude, she sent to the journal a letter which was published in the issue nineteen on 30 July 1891. The publication of the letter was accompanied by a note which says that it would be a great honor for the publication to place in it one of her works'. ${ }^{34}$ In spite of her busy schedule, Olga Sergeevna gave in response her translation of a prose work by Zhukovsky Kto istinno dobriy i schastliviy chelovek? [Who is Genuinely Kind and Happy Person?] which was issued during her second visit in Istanbul.

Olga Sergeevna returned to Istanbul for the second time on 12 October 1891 accompanied by her daughters. In the future, she would spend every winter for four consecutive years in Istanbul. Not only was it necessary for her work but also for her health. What is interesting is the fact that the comment made in Tercüman-ı Hakikat about her second visit was accompanied by an explanation to readers saying that 'for health reasons it was necessary for her to spend the winter in warmer countries. ${ }^{35}$

Upon her second arrival in Istanbul, her translations of Pushkin's Metel [The Blizzard, Lermontov's Demon and a monograph about the life and works of Pushkin entitled Şair Puşkin [The Poet Pushkin] were published in separate edition by printing house of Tercüman-ı Hakikat. Shortly after this, Pushkin's Pikovaya dama [Queen of Spades] was printed by Alem printing house under the name Kâğt oyunu [A Card Game] in big format, on good paper and contained portraits of the author and the translator.

We know through Ahmet Mithat that Lebedeva had made a parallel translation of Pushkin's poem The Fountain of Bakhchisaray into Turkish and Tatar. Unfortunately, neither the year nor the place of its publication has been established. I suppose that this translation was published in Gaspirali Ismail Bey's Crimean newspaper Tercüman [Translator].

During this visit Turkish readers were introduced for the first time to Leo Tolstoy. The translation of

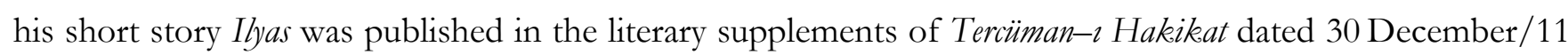
January 1891/2 and 14/26 January 1892 under the title Ilyas yâhut Hakikat-i gina [Ilyas or Truth Wealth] with no indication of the author's name of. Ilyas which was presented to Ahmet Mithat in Stockholm is the first Russian literary work translated by Lebedeva into Turkish. (Figure 4)

From February to June 1892, from the pages of Tercüman-ı Hakikat, Turkish reading public was introduced to the second work of Tolstoy novel Semeinoe schastie [Family Happiness]. The novel, like previous works, was released in a separate edition.

\footnotetext{
34 Serveti Fünûn [Treasury of Knowledge], 18 July 1307 [30 July 1891], pp. 221-22.
}

35 Tercüman-ı Hakikat, 14 October 1307 [26 October 1891], p. 3. 
In the course of the following two months three more translations of Tolstoy's works by Lebedeva were also brought out: Dva starika [Two Old Men] from the series Narodnie rasskazy grafa Tosltogo [Folk Tales by Count Tolstoy], Smert Ivana Ilicha [The Death of Ivan Ilych] and Chem ludi zhivy [What Men Live By?].

That same year (1892), jointly with a popular literary figure and a friend Mustafa Rashid, Lebedeva translated two poems by Lermontov Angel and Parus [The Sail which came out in a collection of poems called Şükuffe-i Istiğrak [The Flower of Oblivion]. It is noteworthy that the full title of the works and the names of their authors were shown here for the first time.

Between 1893 and 1896 information about Lebedeva's stay in Istanbul began to flicker in Russian newspapers Novorossiyskaya gazeta [New Russia], Novoe vremya [New Times] and Volzhskoe vremya [Volzhsky Times], also in the 'Chronicle' section of Sankt-Peterburgskie vedomosti [St Petersburg Gazette]. All of them emphasized her proactive educational activities. ${ }^{36}$

Olga Sergeevna's increased popularity as well as close patronage of Ahmet Mithat disturbed some circles so much that they became the subject of indecent gossip and rumors spread about both Lebedeva and Mithat. ${ }^{37}$

From reading Mithat's letters and reminiscences of guests at his house, one can certainly say that all these rumors were far-fetched. In the first instance, Mithat was newly married and was very happy. It was his second wife - in those days such things were perceived as normal. Moreover, each member of Mithat's large family adored Olga Sergeevna. Sometimes her children came to visit her in Istanbul, and they also stayed at Mithat's home. In the evenings all of them would meet up in the sitting room: Mithat, both his wives, all the children and guests of the house. Lebedeva would tell them Russian folk tales and introduce them to traditional Russian culture. ${ }^{38}$ However, apparently, the gossip forced Mithat to close the doors of his home to the Russian guest.

At Lebedeva's third visit in the winter of 1893, not only had he stopped inviting her to his villa, but he also refused to meet or communicate with her. He did not reply to her letters. We learn this from the correspondence between Mithat and Fatma Aliye. Moreover, in his letters of this period Mithat coldly calls Lebedeva simply 'Gülnar' omitting the courteous 'Khanum', in other words, 'Madame'. ${ }^{9}$ By all accounts, some kind of rift had come between them. Yet, although they reconciled with each other six months later,

\footnotetext{
${ }^{36}$ Karimullin, p. 300.

${ }^{37}$ Midhat, Fazıl ve Feylesof Kızım [My Spiritual and Philosopher Daughter], pp. 98-99.

38 Ibid., pp. 75, 85.

${ }^{39}$ Ibid., pp. 198, 242, 302, 305.
} 
and Mithat again referred to her as Gülnar Khanum, the pages of his newspaper would never again contain any information about Lebedeva and her activities. It is most unfortunate that the letters of Fatma Aliye have not survived, and so the reason of their disagreement remains a mystery.

There were also accusations of espionage. ${ }^{40}$ However, hardly anyone believed them. Mithat himself satirized such suspicions in his letters writing that 'she understands nothing about politics'. ${ }^{41}$ Significant was the fact that she had been awarded by Sultan Abdul Hamid II in 1891.

Of course the times were different. We found in our archives some circulars dispatched between the Istanbul nobility and the Sultan regarding Lebedeva. For example, Olga Sergeevna was friendly with Fatma Aliye whose father Ahmet Cevdet Pasha was an important historian, administrator and advisor to the Sultan. It was he who wrote a petition to the Sultan for permission to have breakfast at Lebedeva's, where he and his daughter had been invited. ${ }^{42}$ Another time he asked for permission to invite Olga Sergeevna to a soirée at his house. ${ }^{43}$

Russian guest was a frequenter of Istanbul cultural elite meetings. On Tuesdays, the first Turkish poetess Nigar Khanum (1856-1918) hosted literary soirees at her house. Following her example, Olga Sergeevna converted her hotel apartment into a similar literary salon for guests, who were well known figures of Turkish cultural and literary circles, such as the first female Turkish novelist Fatma Aliye, the poetess Nigar Khanum, the poet and writer Mustafa Rashid and others. Upon Lebedeva's return to her homeland, they continued to maintain a friendly correspondence. I managed to find four of her letters and greeting cards to Nigar Khanum - two of them are in French and two in Ottoman Turkish. There is an interesting monogram of Olga Lebedeva on the letter from Saint Petersburg (11/23 March 1897) written in Ottoman and its envelope. (Figure 5)

Lebedeva loved Istanbul. In the letter to Nigar Khanum (in French) dated 19/31 January 1897 she has nostalgia for the Bosphorus and admits that she is attached to Istanbul with all her heart. Here she reflects on how busy she had been there and how little time she had had. In those days, she bustled about the Imperial Society of Oriental Studies established by her in February $1890{ }^{44}$ The Russian tsarina, the wife of

\footnotetext{
40 Ahmet Rasim, Matbuat Hatıralarndan: Muharrir, Şair, Edip [From His Issued Memoirs: Publicist, Poet, Writer] (Istanbul: Kanaat Kütüphanesi, 1924), pp. 208-09.

41 Ibid., p. 193.

${ }^{42}$ Istanbul, Prime Ministry Ottoman Archives (PM OA), Y.EE fonds, fol. 15.214.H16.12.1309.

43 PM OA, Y.EE fonds, fol. 79.17.24.04.1309.

${ }^{4}$ Ves Peterburg na 1902: adresnaya i spravochnaya kniga g. S. Peterburga [All Petersburg: Address and Reference Book of St Petersburg for 1902] (St Petersburg: A. S. Suvorin, 1902), p. 356.
} 
Nicholas II, Alexandra Feodorovna, would become the Patron of the society (in 1911) and Olga Lebedeva its honorary President (in 1900).

Besides this, she was busy with educational activities for Russian Tatars. It is known that in 1893 upon her return to Russia from Istanbul, she met the head of the main administrative department dealing with the press at the Ministry of Internal Affairs and the Chief censor in Russia, Evgenii M. Feoktistov in order to introduce him to her plans to open a secular Tatar school and to issue a new Tatar-Russian newspaper. All her efforts turned out to be unsuccessful. In addition, the police would keep her under surveillance and she would be suspected of conversion to Islam, which could lead to all kinds of spiritual punishments by the Synod church. ${ }^{45}$

The denial of the publication of the newspaper was a heavy blow to Olga Sergeevna. All her plans were ruined and she left the capital to return to her home place and stay in solitude. At her country house in the Spassky District of Kazan Province she began her translation activity again, continued to study the history and culture of the Orient, and often visited Kazan to meet academic orientalists at the university and Tatar intellectuals. She was so busy that she did not manage to fulfill a request to publish her works in the new Turkish magazine Hanmlara Mahsus Gazete [Magazine for Ladies], for which she sent a letter of apology on 12 October 1311/24 October $1895 .^{46}$

In 1895 Olga Sergeevna published a comprehensive study on Russian literature (totaling 132 pages), aimed at the Turkish readership, which will become her last work published in Ottoman Turkish.

At the beginning of 1896 a notice appeared in newspaper Ikdam [Progress] stating that Olga de Lebedeff was translating Leo Tolstoy's short story Hozyain i rabotnik [Master and Man] ${ }^{47}$, however, we have not found any evidence about its publication in Turkey.

\section{LEbEDEVA's Translations AND Literary CRITICAL STUdies IN THE OTTOMAN EMPIRE}

The determination of Olga Lebedeva's works in the Ottoman Empire still reveals some problems. Some sources often quote studies which cannot be identified. It seems as if the following works by Olga Sergeevna Lebedeva were published in Turkish.

\footnotetext{
45 Karimullin, p. 150.

46 Akün, p. 247.

47 Ibid.
} 


\section{THE OTTOMANS}

1. The Blizzard by A. S. Pushkin $(1891)^{48}$

2. Demon by M. Y. Lermontov $(1891)^{49}$

3. The Poet Pushkin $(1891)^{50}$

4. The Relation of Islam to Science and the Heterodoxes by A. Bayazitov $(1891)^{51}$

5. Islam and Science, Objections to Renan by A. Bayazitov (1891) ${ }^{52}$

6. Who is Genuinely Kind and Happy Person? by V. A. Zhukovsky (1892) ${ }^{53}$

7. Queen of Spades by A. S. Pushkin (1892) $)^{54}$

8. Angel by M. Y. Lermontov (1892) $)^{55}$

9. The Sail by M. Y. Lermontov $(1892)^{56}$

10. Two Old Men: from the Folk Tales of Count Tolstoy $(1892)^{57}$

11. The Death of Ivan Ilych by L. N. Tolstoy $(1892)^{58}$

12. What Men Live By? of L. N. Tolstoy $(1892)^{59}$

13. Ilyas by L. N. Tolstoy (1893) ${ }^{60}$

14. Family Happiness by L. N. Tolstoy (1893) ${ }^{61}$

\footnotetext{
${ }^{48}$ Kar Firtınası. Puşkin'den Tercüme [The Blizzard. Translation from Pushkin], trans. by Gülnar Olga Dölebedeff (Istanbul: Tercüman-1 Hakikat Matbaas1, 1308 [1891]).

${ }^{49}$ Lermontof'un Iblisi [Lermontov's Demon], trans. by Gülnar Olga Dölebedeff (Istanbul: Tercüman-1 Hakikat Matbaas1, 1308 [1891]).

50 Gülnar de Lebedeff, Şair Puşkin [The Poet Pushkin], (Istanbul: Tercüman-1 Hakikat Matbaası, 1308 [1891]).

51 Ayatullah Bayazidof, Islamiyetin Maarife Taalluku ve Nazar-I Muarizinde Tebyini [The Relation of Islam to Science and the Heterodoxes], trans. by Olga de Lebedeff and Ahmet Cevdet (Istanbul: Tercüman-1 Hakikat Matbaas1, 1308 [1891]).

52 —, Islâmiyet ve Fünûn, Redd-i Renan [Islam and Science, Objections to Renan], trans. by Olga de Lebedeff and Ahmet Cevdet (Istanbul: Tercüman-1 Hakikat Matbas1, 1308 [1891]).

53 Zhukovsky, 'Hakikaten Iyi ve Mesut Adam Kimdir? ['Who is Genuinely Kind and Happy Person?'], trans. by Gülnar Dölebedeff, Serveti Fünûn, 26 March 1308 [7 April 1892], pp. 50-52

${ }^{54}$ Kâğıt Oyunu. Pushkin'den Tercüme [A Card Game. Translation from Pushkin], trans. by Gülnar Lebedeff (Istanbul: Alem Matbaas1, 1309 [1892]).

${ }_{55}$ Mikhail Yuryevich Lermontov, Melek [Angel] in Şükûfe-i Istiğrak [Flower of Oblivion], trans. by Mustafa Reşid and Gülnar Khanum (Istanbul: Alem Matbaas1, 1310 (hijri) [1892]), p. 25.

56 _, Yelken [The Sail] in Şükûfe-i Istiğrak [Flower of Oblivion], trans. by Mustafa Reşid and Gülnar Khanum (Istanbul: Alem Matbaas1, 1310 (hijri) [1892]), p. 26.

57 _- Avama Mahsus Hikayeleri: Iki pir [Two Old Men: from the Folk Tales of Count Tolstoy], trans. by Olga Dölebedef, Tercüman-ı Hakîkat, lit. sect. 4133, 4 April 1308 [16 April 1892].

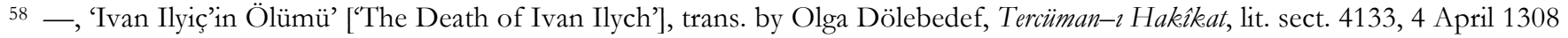
[16 April 1892].

59 —, 'Insan ne ile yaşar?' [What Men Live By?], trans. by Olga Dölebedef, Tercüman-ı Hakîkat, lit. sect. 4146,24 April 1309 [6 May 1892].

${ }^{60}$ Ilyas, yâhut, Hakikat-i gina [Ilyas or Truth Wealth], trans. by Gülnar Mme Olga Dölebedef (Istanbul: Tercüman-1 Hakikat Matbaas1, 1310 [1893]).

61 Count Tolstoy, Familiya saadeti [Family Happiness], trans. by Madame Gülnar (Istanbul: Tercüman-1 Hakikat Matbaas1, 1310 [1893]).
} 


\section{The City of Kazan $(1893)^{62}$ \\ 16. Russian Literature $(1895)^{63}$}

Thirteen of all sixteen work of Lebedeva published in Istanbul are related to Russian literature. Among them, there are five short stories and tales by Tolstoy, three lyrical works by Lermontov, two short stories by Pushkin, the discourse by Zhukovsky and two literary critiques. Overall, the theme of the majority of these is based on happiness; in some cases - happiness is spiritual, in others personal or within the family. But in all, the common theme or 'red thread' running through them is a belief in God and compassion. Motives of fate and loneliness accompany this theme of happiness.

How can one explain the choice of these works, which are often not the most famous ones?

In the case of Ilyas the logic is clear. The story of Ilyas, a Bashkir, is close to Turkish culture. In other respects, I believe, Lebedeva was guided by her own personal inclinations. It is not surprising that she translated The Blizzard and not The Station Master from Belkin's Tales by Pushkin. One can explain the choice of Family Happiness and the discourse $W$ ho is Really is a Good and Happy Person? Most probably, Olga Sergeevna did not have a happy family life - several quotes by Mithat in his correspondence with Fatma Aliye allow to conclude that Levedeva had difficult relationship with her husband.

Only five of the translations mentioned above came out in separate editions, namely: The Blizzard (totaling 61 pages) and The Queen of Spades by Pushkin (totaling 38 pages), Demon (totaling 96 pages) by Lermontov, Ilyas (totaling 30 pages) and Family Happiness (totaling 82 pages) by Tolstoy.

There had been six female translators including Lebedeva since 1839, the period of Turkey's reorganization named Tanzimat until 1908, the Second Constitutional period. The total number of translations published by them as a separate book was ten. ${ }^{64}$ Given this information, the five publications by Olga Sergeevna show her to have been the most productive translator during the period.

There are no exact facts relating to the quantity of books published by Lebedeva. Judging by the letter she sent to Leo Tolstoy 'All these translations were very successful and were sold very well... ${ }^{65}$ Shifman indicates in his article that there was a circulation of forty thousand copies of the translations. ${ }^{66}$ I believe, the

\footnotetext{
${ }^{62}$ Olga Dölebedef, 'Kazan Şehri’ ['The City of Kazan'] in Serveti Fünûn, 25 March 1309 [6 April 1893], pp. 55-58.

${ }^{63}$ Gülnar de Lebedeva, Rus Edebiyatı [Russian Literature] (Istanbul: Asadorian Matbaas1, 1311 [1895]).

${ }^{64}$ Ayşe Banu Karadağ, 'The Traces of Feminity of Woman Translators from The Tanzimat to The Second Constitution in Our Translated Literary History', Humanitas International Journal of Social Sciences, 2 (2013), 105-126.

${ }^{65}$ Shifman, p. 404.

66 Ibid.
} 
popularity of Lebedeva was greatly exaggerated. The percentage of literate people in those days was very low. A circulation of forty thousand copies at that time sounds sky-high. The Tercüman-ı Hakikat was one of the most popular newspaper in Istanbul, but once again, the circulation numbers were not archived.

Lebedeva's translation of Russian literary works did have great success which was greatly facilitated by the editorial work of Ahmet Mithat Efendi and Ahmet Cevdet, from whom Lebedeva took lessons of the Ottoman language. It should be noted that Ahmet Mithat treated the editing of the text very delicately. He stressed not only in the forewords to the translations but also later in his letters to Fatma Aliye that he had hardly made any corrections and that he tried in every way to keep Lebedeva's stylistic harmony, unlike the editor Ahmet Cevdet who greatly altered the style of the last translations. ${ }^{67}$

Each publication, with the exception of The Queen of Spades, was prefaced with a foreword, some of them had two - from both publisher and translator.

In the foreword to The Blizzard - the story about the curious event of an unexpected marriage of a young soldier and a young provincial girl - after some short words of praise about Pushkin, Ahmet Mithat reflects on his meeting with Madame Gülnar and how valuable her company turned out to be during his trip around Europe. Emphasizing her belonging:

to a rich and famous aristocratic family from Kazan, as a sign of gratitude for the goodwill shown by this noble and wealthy lady to the Ottoman language and her intention to translate the best works of the Russian language ${ }^{68}$

Mithat explained his desire to publish translations made by her. His foreword ends with an observation about editing these translations, which says that 'in order to keep the originality of text' the corrections 'comprise barely twenty five percent, and the remaining seventy five is the translator's wording, ${ }^{69}$

At this point it should also be noted that it was not only Mithat Efendi who was intrigued by her efforts in the area of translation, but also other representatives of Turkish culture, in addition, there was a simple curiosity. Another important aspect was great respect of representatives of the Ottoman Empire for western scholars specialized in the Islamic and Ottoman language and culture. The term 'outstanding

\footnotetext{
${ }^{67}$ Midhat, Fazıl ve Feylesof Kızım [My Spiritual and Philosopher Daughter], p. 305.

${ }^{68}$ Kar Furtınası. Puşkin'den tercüme [The Blizzard. Translation from Pushkin], pp. 3-4.

${ }^{69}$ Ibid., p. 5.
} 
orientalist' (fazila-i müsteşrik) $)^{70}$, applied to Madame Gülnar, expressed nothing but admiration and recognition.

In the introduction to Lermontov's poem The Demon, which is based on the love of an evil spirit expelled from the heaven by God to mortal Tamara, there were two entries: the first one was quite brief and was written by Ahmet Mithat, and the second one - by the translator. In his preamble, Mithat Efendi admires Madame Gülnar's performance calling her 'an outstanding academic orientalist' and announces the publication of the next work's translation. Mithat explains the high style of the Ottoman text by the choice of the work and a wish to transmit the form and content of the original into Ottoman. Mithat emphasizes the adequacy of the translation and development of Madame de Lebedeffs translational skills. Regarding his involvement in the editing of the text, Mithat writes that his contribution is insignificant for categorizing himself as an editor. ${ }^{71}$

The Translator's Entry starts with the question like:

What was the main aim of the author in this work? It is hard to define this. Despite the difficulty in determining the goal of the author, it is clearly seen that he refers to myths and legends. The story places special emphasis on morality and decency purity, beauty and love are stronger than tyranny, guilt and dishonesty. The actual theme, the wonderful poetry, and the magnificent descriptions of nature, are so fascinating that Rubenstein wrote an opera. ${ }^{72}$

Thus in order to properly transmit the whole beauty of the work in her translation, Lebedeva took the 'the best sections from both the original and the opera. ${ }^{73}$ In the conclusion she expresses the hope that readers will like her modest translation and that it will be duly appreciated.

Leo Tolstoy's Ilyas, which tells the story of Bashkir from Oufa named Ilyas and his wife, freed from the shackles of wealth, find genuine happiness, was published under the title of Ilyas or Truth Wealth without the authors' name indication. We learn about Tolstoy's authorship from the introduction written by Ahmet Mithat. However, it is to be noted that the emphasis was placed not on Tolstoy or his story but on the study

\footnotetext{
${ }^{70}$ Ibid.

${ }^{71}$ Lermontof'un Iblisi [Lermontov's Demon], p. 3.

72 Ibid., p. 4.

73 Ibid.
} 
of Lebedeva's translation. From the introduction we learn that Ilyas was Lebedeva's first translation of Russian fiction into Turkish. Considering the translation deficient, Lebedeva had no intention to publish it, however, Ahmet Mithat, having been touched by the memory of Ilyas which had been gifted to him by Lebedeva on their first acquaintance in Stockholm, completely edited it and had it printed in his newspaper. $^{74}$

In the foreword to the novel Family Happiness Lebedeva shares Tolstoy's conviction that a woman's calling is comprised not of freedom of expression of her 'natural' feelings, but of realization of her marital duties as a 'true' calling, and claims that real happiness can be obtained only in the hearth and home. She advises the young women and men to married an build true family happiness on the basis of trust, faithfulness and mutual understanding. ${ }^{75}$

Creative activity of Olga Lebedeva to acquaint Turkish readers with achievements of the Russian culture was not limited to translations only. She had also published literary critiques, wishing to provide her readers with background information on the writers and their art, including interpretation of the translated works.

The first of these was The Poet Pushkin - an essay on the life and work of Alexander Pushkin. The monograph also includes a short summary of several works of the world literature genius: Eugene Onegin, Poltava, The Captain's Daughter, The Bronze Horseman, Boris Godunov, as well as some texts of the great poet that formed the basis for a number of musical compositions.

Aiming at drawing attention of literature fans to this essay, it was introduced by Ahmet Mithat Efendi who called Pushkin the 'greatest of Russian writers'. To highlight the poet's uniqueness Mithat Efendi expressed his opinion that Pushkin had had a great influence not only on Russian but also on all European literature. $^{76}$ The Lebedeva's essay on Pushkin was republished in the Servet-i Fünun starting from issue one hundred six on 10 March 1309/22 March 1893.

Another piece of writing signed by Gülnar de Lebedeff is Avrupa Meşâhiri Mubarririni Lermontov [The Famous European Writer Lermontov]. A short article, published in the Servet-i Fünûn on 29 April 1309/11 May 1893, introduces Lermontov to the Turkish readers starting with the poet's small picture at the top and

\footnotetext{
${ }^{74}$ Ilyas, yâhut, Hakikat-i gina [Ilyas or Truth Wealth], p. 3.

75 Ibid., p.5.

${ }^{76}$ Lebedeff, Şair Puşkin [The Poet Pushkin], p. 7.
} 
THE OTTOMANS

information on his Scottish origin. ${ }^{77}$ Actually it was the preface to the translated by Lebedeva Lermontov's Demon.

In 1895 Olga Sergeevna published a more comprehensive work - a study of Russian literature Rus Edebiyat in one hundred thirty two pages. (Figure 7) The first nine pages of the essay outline a short explanation of the origins and evolution of Russian literature until the eighteenth century; from the tenth page onwards there follow nineteen character portraits of famous writers, starting with Antiokh Kantemir (p. 11) and ending with Leo Tolstoy (pp. 130-132). Readers are also carefully introduced to the works of M. V. Lomonosov (pp. 12-23), G. P. Derzhavin (pp. 24-31), D. I. Fonvizin (pp. 32-35), N. M. Karamzin (pp. 35-50), I. I. Dmitriev (p. 51), M. M. Heraskov (pp. 52-53), V. A. Zhukovsky (pp. 53-58), K. N. Batiushkov (pp. 58-61), I. A. Krilov (pp. 61-63), A. S. Pushkin (pp. 64-93), A. S. Griboedov (pp. 94-95), M. Y. Lermontov (pp. 95-107), A. V. Koltsov (pp. 107-109), N. V. Gogol (pp. 109-118), I. A. Goncharov (pp. 119-121), I. S. Turgenev (pp. 121-124), A. N. Ostrovsky (pp. 124-130) together with the content of works which later became the world classics. It is striking to note that names of such great writers as F. M. Dostoevsky and A. P. Chekhov are absent in this study. ${ }^{78}$

Although in some parts (as parts related to Kantemir, Dmitriev and Heraskov) the writers were introduced in a general framework, in the monographs, by the large, it has been attempted to present sources the artists nourished from and the art sensibility they were affected by. Normally, at the beginning, writers' short biography is given, together with information on his origin, family circle, information about belonging to an aristocratic class or coming from the folk. Moreover, the type of the work is indicated and its basic features are focused on. The biggest part of the monograph is devoted to Lomonosov, Pushkin, Lermontov and Gogol. Starting from the family circle and the upbringing tradition of the writers under discussion up to their works' specifications, a detailed explanation and inspection can be found there. It has been observed that Lebedeva, in the Pushkin and Lermontov parts, benefitted from works done on the writers earlier.

\footnotetext{
77 Gülnar de Lebedeff, ‘Avrupa Meşâhir-i Muharririni Lermontof' ['The Famous European Writer Lermontov'], Servet-i Fünûn, 11 May 1309 [23 May 1893], pp. 134-37.

${ }^{78}$ Why Lebedeva decided to do this is not clear. In 1895 Dostoevsky had already died, i.e. all his novels had been published and were famous. Although Chekhov was not yet known as a genius writer in 1894/5, he managed to publish his several stories. It could be that Lebedeva used some sort of textbook as her source in which somehow these authors were not featured. This is also indicated by the fact that she included L. N. Tolstoy as an addition due to her personal acquaintance and correspondence with him.
} 
The Russian Literature is completed with a short statement made under the heading Lâhika (Inference), where it is stated that there are many other artists in Russian literature. However, it is also reported that 'all of them could not be included in order to avoid the expansion of the book too much. ${ }^{79}$

Through this book Turkish reader learnt about the works of fifteen Russian writers more. As a result, with the exception of Dostoevsky and Chekov, the Turkish reading public was presented with a wide panorama of the Russian literature.

Very different in character are the works by the Tatar educator and Imam of the Muslim community in St Petersburg Ataullah Bayazitov (1846-1911): the book Otnoshenie islama k nauke i inovertsam (1887) [The Relation of Islam to Science and the Heterodoxes] and the essay Vozrazheniya na rech Ernsta Renana, skazannuyu $v$ nauchnoy Frantsuzskoy assotsiatsii (1883) [Objections to Ernst Renan, spoken at the French Academy of Sciences]. They were translated by Lebedeva jointly with the editor of the Tercüman-ı Hakikat Ahmet Cevdet from Russian into Turkish at the request of Ahmet Mithat Efendi.

Ways of analysis of Islam, its place in the life of the Muslim society and, as a whole, in the world civilization, as well as reconciliation of principles of the modern civilization with the spirit of Islam, were widely appreciated in the Ottoman society.

\section{LEBEDEVA's ACTIVITIES AT THE END OF THE 1890s AND BEGINNING OF THE 1990s}

By the end of the 1890s, Olga Sergeevna's activities were focused on a research of oriental studies, the results of which were either variously presented at Orientalist congresses, or published separately.

Thus, Ahmet Mithat shares in his letters evidence about Lebedeva's preparations for the Ninth, Tenth and Eleventh Congresses of Orientalists in London (1892), Geneva (1894) and Paris (1897). However, we have not managed to find her name written either in the programs, or in the lists of participants of these particular congresses. Nevertheless, it must be said that her name was not on the program of the Eighth Congress in Stockholm either, where she met Mithat Efendi. The mystery is uncovered by Ahmet Mithat Efendi's book from which we know that Olga Lebedeva was not there as a part of the official delegation, but came to the Congress in Stockholm at her own expense as an individual participant.

From the study of Boris Dantsig Blizhny vostok [Near East] we know that she took part in the Twelfth Congress of Orientalists in Rome in 1899 with two reports about 'an edict, addressed to the hetman

\footnotetext{
${ }^{79}$ Lebedeva, Rus Edebiyatı [Russian Literature], p. 132.
} 
THE OTTOMANS

(military commander) Bogdan Khmelnitsky by the Grand Vizier Ibrahim, which instructs to ask the Crimean Khan Giray for support and help to fight against Poland' and about 'position of women in the Caliphate. ${ }^{80}$

Additionally, a report on the history of the Kazan and Tatar people was published in a separate book in the French language in Rome. ${ }^{81}$ Figure in it the author discusses in detail the history of conquest of the Kazan Khanate by the Moscovy. Considerable attention is given to the ancient history and culture of the Tatars, the state of schooling, literacy, population and the social position of Tatar women.

At the Thirteenth Congress in Hamburg in 1902 Olga Lebedeva presented a lecture on the rights of women in the Muslim Orient (it was read by I. Goldberg). ${ }^{82}$

In 1905 on behalf of the Russian Society of Oriental Studies she participated in the Fourteenth Congress in Algiers. At the opening ceremony she gave a speech on behalf of Russian academics on the topic Notes on an Arabic manuscript about the history of conversion of the Georgians to Christianity (in French). ${ }^{83}$

Lebedeva would also speak at the Sixteenth Congress in Athens on behalf of the Russian Imperial Society of Oriental Studies in 1912. The topic of her lecture was About Sufism in Relation to the Partial Translation of al-Aushi's Treatise. ${ }^{84}$

All titles of Lebedeva's lectures and works demonstrate the wide scope of her academic interests and deep erudition. Some of her works were published in Russia and beyond its borders. For example, the work Ob emantsipatsii musulmanskoy zhenshchiny [On Emancipation of Muslim Women] came out in Russian (St Petersburg, 1900) (Figure 7) and in French ${ }^{85}$ (Cairo, 1906). The Turkish translation of the same work would come out in the journal Kadyn [Woman] in 1909 in Thessaloniki. ${ }^{86}$ The work's last publication in Turkey in translation from Tatar dates from 1919. The last residential archive to list her address is found in St Petersburg dated 1913. Unfortunately, from that date information about Olga Sergeevna Lebedeva stopped to exist. What became of her fate thereafter is unknown.

\footnotetext{
${ }^{80}$ B. M. Dantsig, Blizhny vostok [Near East] (Moscow: Nauka, 1976), p. 318.

81 Olga de Lébédeff, Abrégé de l'histoire de Kazan [The Short History of Kazan], (Rome: Societa editrice Dante Alighieri, 1899).

${ }^{82}$ Dantsig, p. 310.

83 Histoire de la conversion des Géorgiens au christianisme, par le patriarche Macaire d'Antioche. Traduction de l'arabe par Mme Olga de Lébédew (Rome: Casa editrice italiana, 1905).

${ }^{84}$ Dantsig, p. 320.

85 'De l'émancipation de la femme musulmane' was published in the series of Içtihat [Opinion], the journal published by Abdullah Cevdet Karlıdă (1869-1932) in Cairo.

86 Olga de Lebedeff, 'Islam Kadınlarında Hürriyet' ['On Emancipation of Muslim Women’], trans. by A. Ulvi Kadin [Woman], issues 12-15, 29 December-19 January 1324 [1908].
} 
The research allows stating that Olga Sergeevna Lebedeva was without any exaggeration the most outstanding personality of her time who deserves to be written up in the annals of the history of Oriental studies. Having received the order of Compassion from the hands of the Ottoman Sultan, Lebedeva justified the symbolic name of this high award, and became, to the best of her capacity, a compassionate intermediary between Europeanized Turkish and Russian societies, which despite their geographical proximity had known very little about each other. The pen name Madame Gülnar has been noted down in golden letters in the history of translations of Russian literary works in Turkey. ${ }^{87}$ She was one of the first to introduce the Turkish people to the great names of Russian literature and promoted the cultural dialogue between the Ottoman and Russian Empires against the background of a complex political situation. She fully deserves her repute of the ambassador of Russian culture who won the hearts of the Turks.

Note: Carina Hamilton provided the translation of this article from the Russian original into English.

\footnotetext{
${ }^{87}$ See Türkan Olcay, 'Russkaya literatura v Turtsii' [Russian Literature in Turkey], Visnik. Kharkivskogo nats. universitetu im. V. N. Karazina, 595 (2003), pp. 91-94; - 'Iz istorii pervih perevodov russkih hudozhestvennih proizvedeniy v Turtsii' [On the History of the First Translations of Russian Literary Works in Turkey] Russian literature in the context of world culture, vol. 1, part 1, St Petersburg, (2008), pp. 362-370; — , 'Obzor na prevodite na ruska literatura v Turtsia (1884-2005) [Overview of the Translations of Russian Literature in Turkey (1884-2005)], Slavyanski Dialozi, 9, (2009), pp. 159-173.
} 

THE OTTOMANS

\section{LIST OF FIGURES}

Figure 1. Ahmet Mithat Efendi (1844-1912) (Photo is from the Lütfü Seymen Archive)

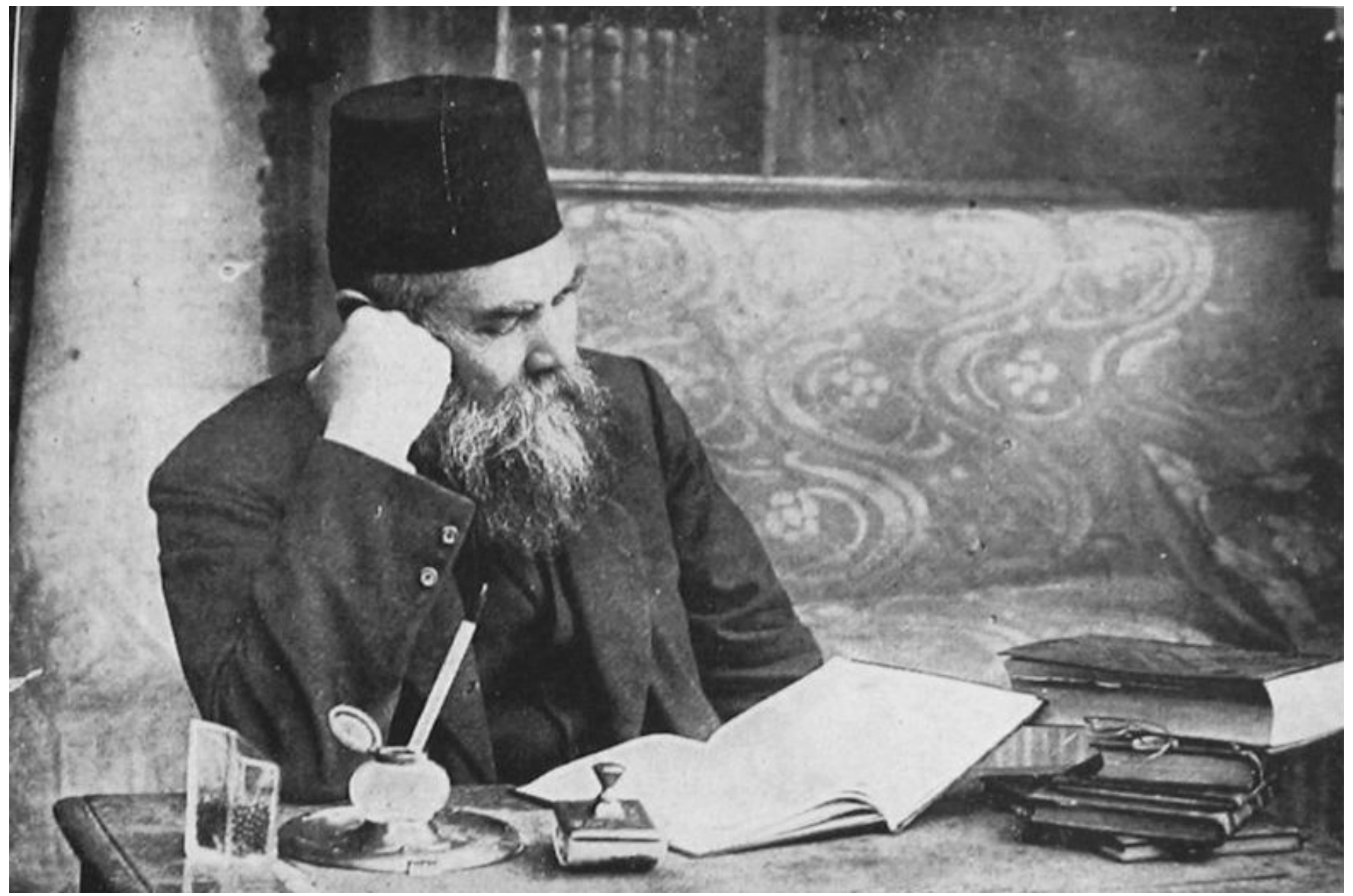



THE OTTOMANS

Figure 2. View of the Golden Horn from the Hotel Londres (Istanbul, 1891). (Photo is from the hotel Londres Archive)

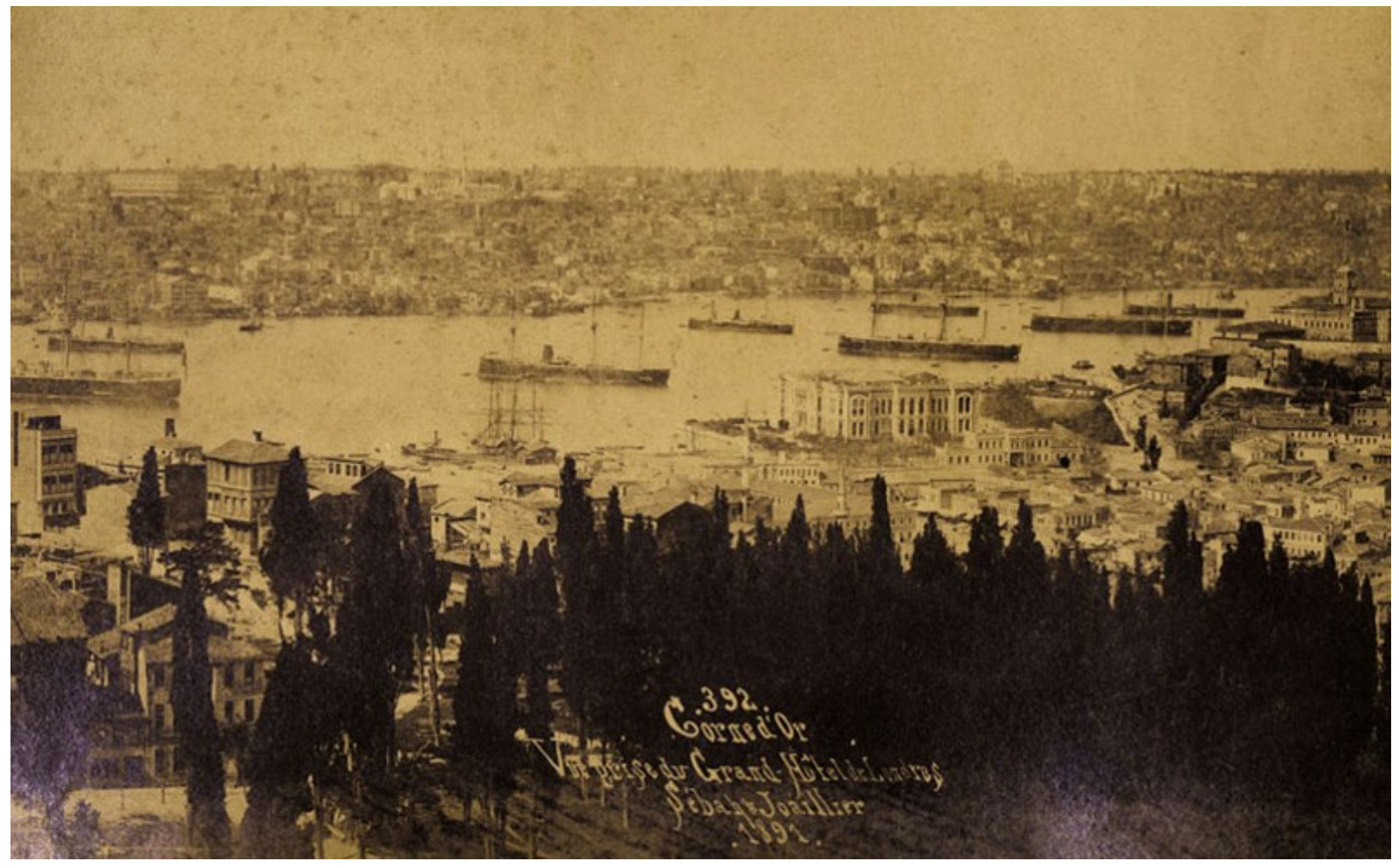



THE OTTOMANS

Figure 3. Photo of Olga Lebedeva from the article in Serveti Fünûn, 20 June 1890, p. 170. (Beyazit State Library, Hakk1 Tarık Us Collection)

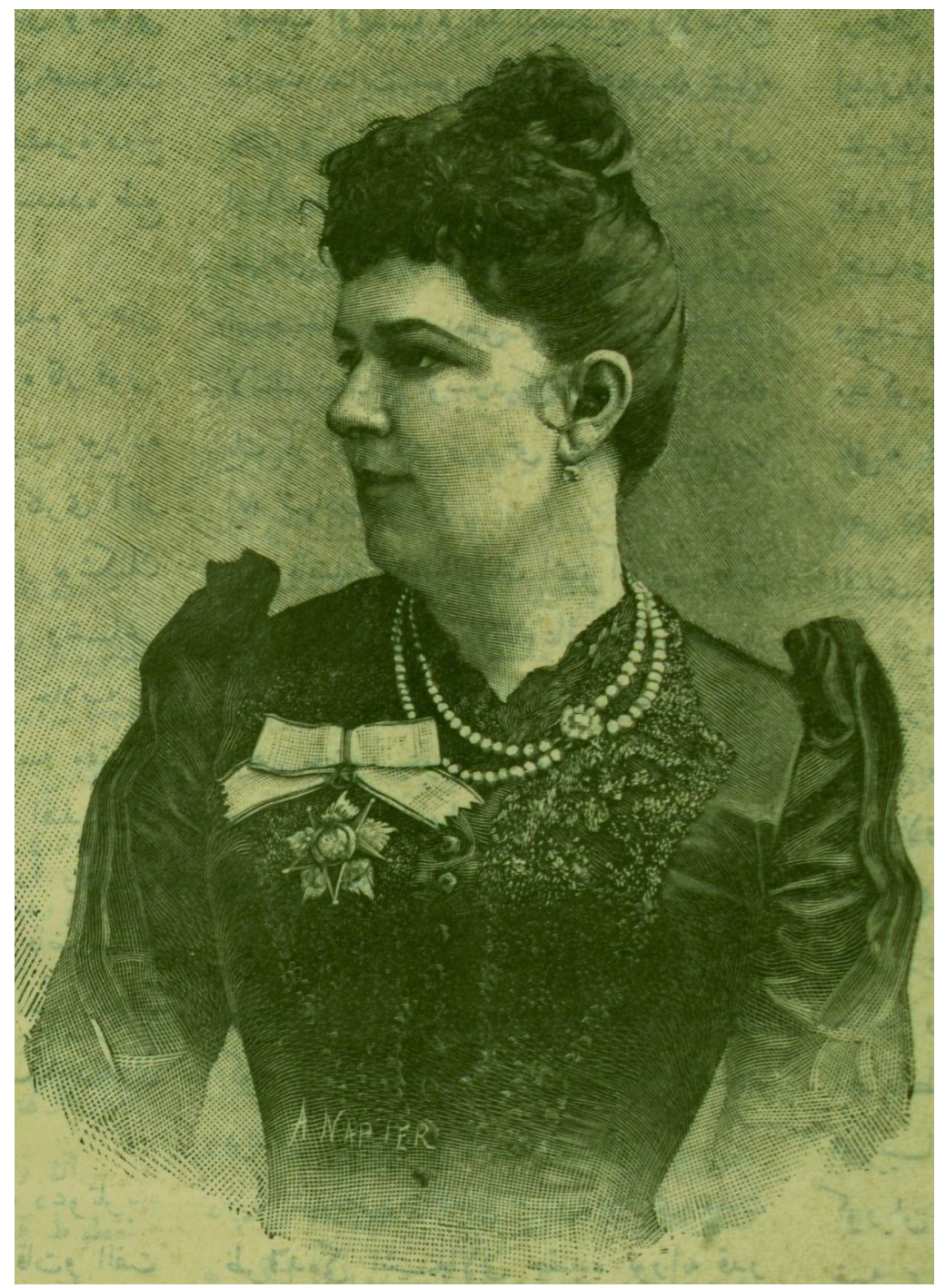


Figure 4. Ilyas or Truth Wealth, trans. by Gülnar Mme Olga Dölebedef, Istanbul, 1310 [1893]. (Beyazit State Library, Hakk1 Tarık Us Collection)

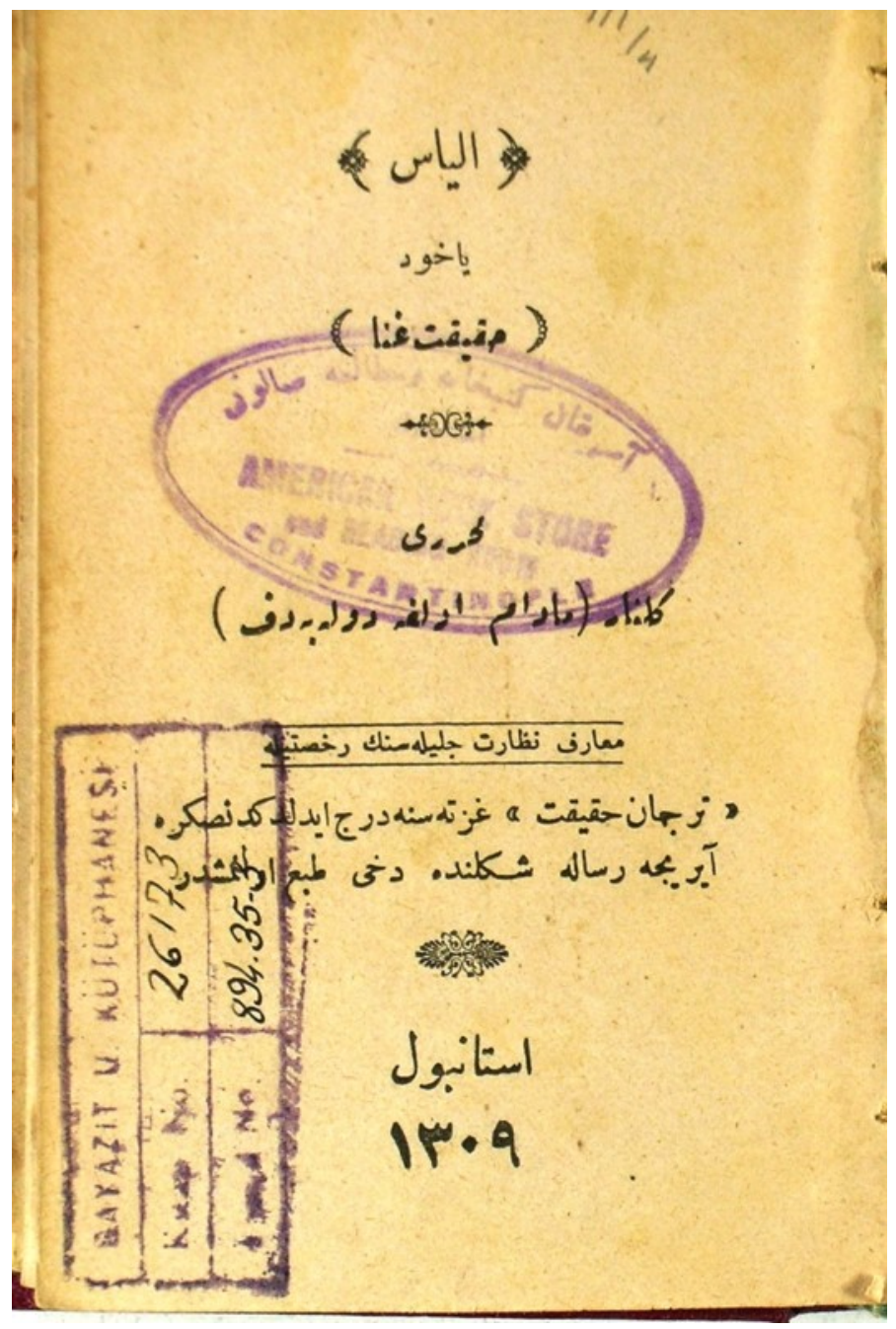


66 OlCAY - Olga LEBEDEVA (MADAME GÜlnAR): A Russian ORIETANTLIST AND TRANSLATOR ENCHANTS THE OTTOMANS

Figure 5. Olga Lebedeva's Letter to Nigar Khanum from Saint Petersburg (11/23 March 1897). (Istanbul Museum of Literature, Nigar Khanum Fond)

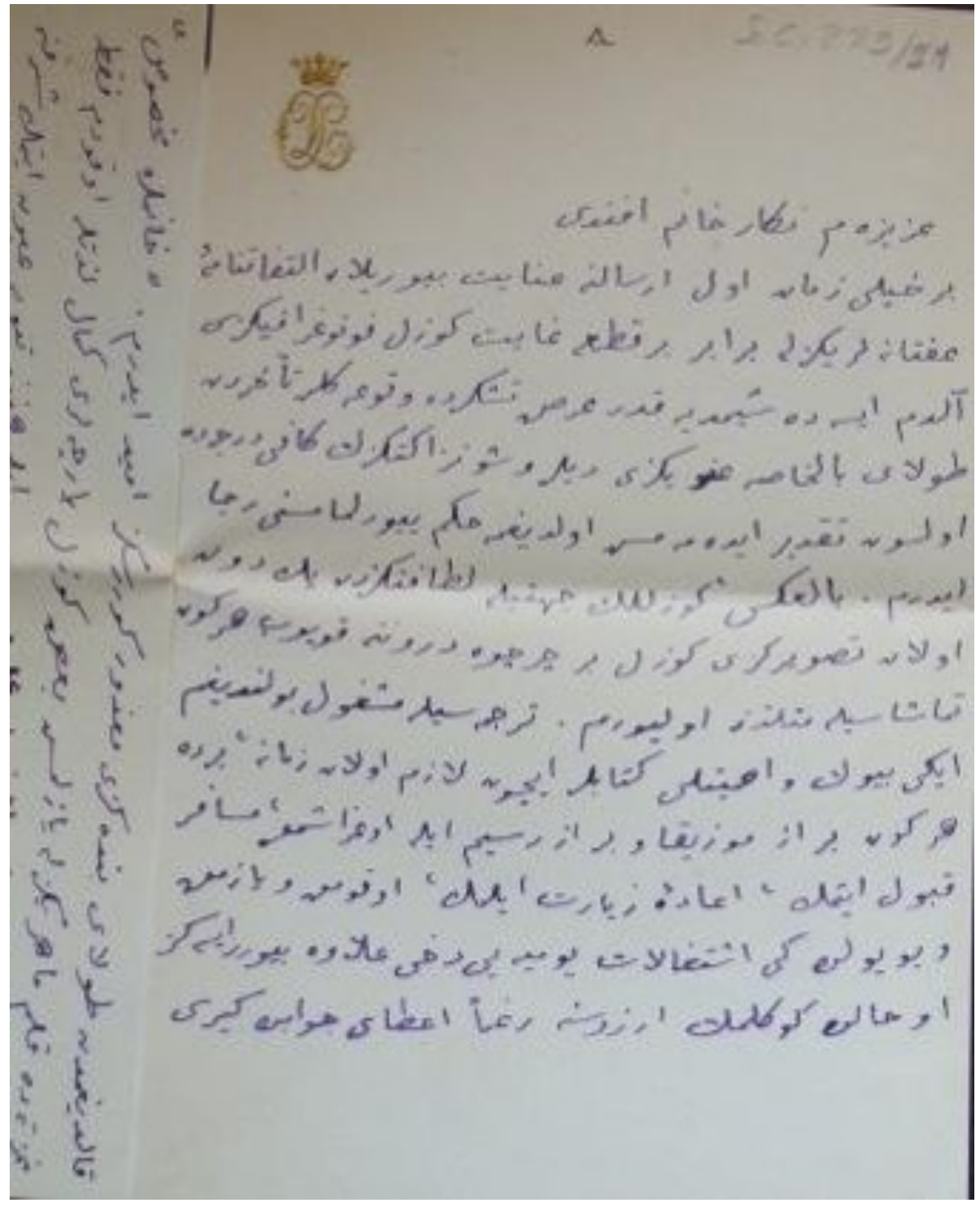



THE OTTOMANS

Figure 6. Russian Literature by Gülnar Lebedeva, Istanbul, 1311 [1895]. (Beyazit State Library, Hakk1 Tarık Us Collection)

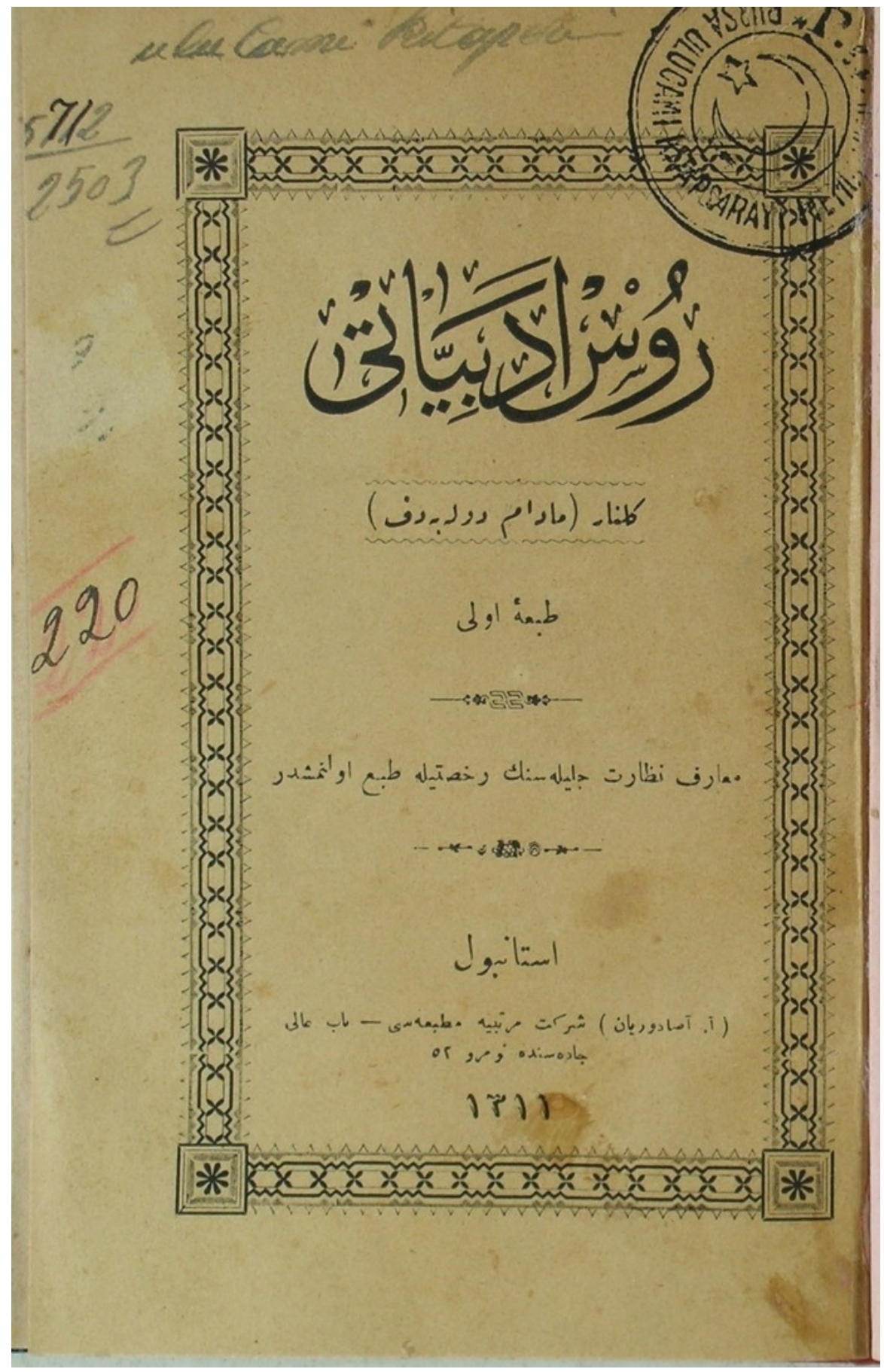



THE OTTOMANS

Figure 7. O. S. Lebedeva, On Emancipation of Muslim Women, St Petersburg, 1900.

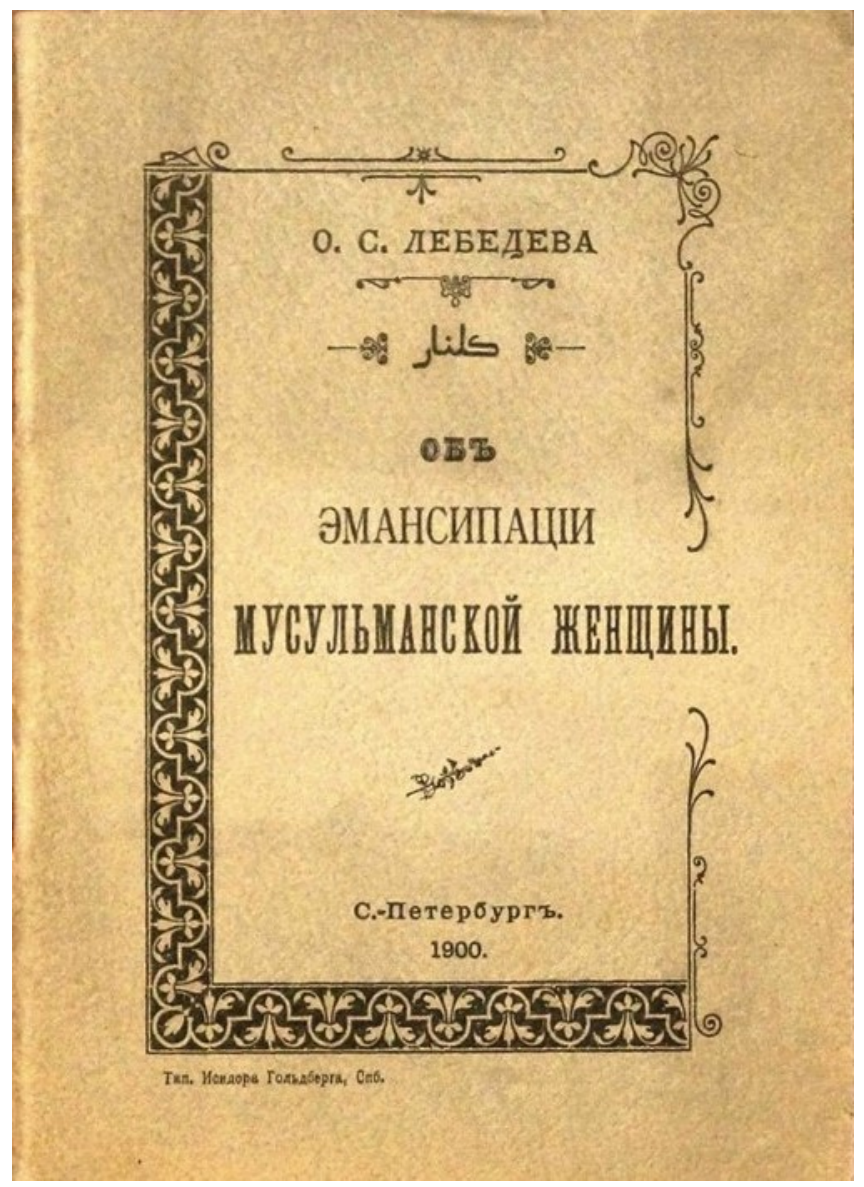




\section{REFERENCES}

Akün, Ömer Faruk, 'Gülnar Khanum' in Islâm Ansiklopedisi (Encyclopedia of Islam), 44 vols, ed. by A. Topaloğlu (Istanbul: TDV, 1988-2013), XIV (1996), pp. 243-248.

Argunşah, Hülya, Kadın ve Edebiyat. Babasınn Kı̨ı Olmake (The Woman and Literature. Being The Daughter of Your Father), (Istanbul: Kesit Yayinlar1, 2016).

—, Kadnn ve Edebiyat. Kendini Yazmak [Women and Literature. Writing yourself], (Istanbul: Kesit Yayınları, 2016).

Bekiroğlu, Nazan, Unutulmuş Bir Müsteşrik: Olga dö Lebedeff / Madam Gülnar’ ('Forgotten Orientalist: Olga dö Lebedeff / Madam Gülnar'), Dergâh, 46 (1993), 8-10.

Dancig, B. M., Bliz̧hniy vostok (Near East), (Moscow: Nauka, 1976).

Findley, Carter V., Ahmet Mithat Efendi Avrupa'da (An Ottoman Occidentalist in Europe: Ahmed Midhat Meets Madame Gülnar, 1889), trans. by Ayşen Anadol (Istanbul: Tarih Vakfi Yurt Yayınlar1, 1999).

Gorohova, L. V.., ed., Dostoini pamyati potomkov. Gorodskie golovy Kazani 1767$1917 \mathrm{gg}$. (Worthy of the memory of the descendants. City Heads of Kazan in 17671917), (Kazan: Gasyr, 2002).

'Gülnar Hanım namı diğer Olga de Lebedeff' ('Gülnar Khanum or so-called Olga de Lebedeff), Serveti Fünûn (Treasury of Knowledge), 20 June 1307 [2 July 1891], pp. $170-73$.

Ilyas, yahut, Hakikat-i gina (Ilyas or Truth Wealth), trans. by Gülnar Mme Olga Dölebedef (Istanbul: Tercüman-1 Hakikat Matbaas1, 1309 [1891]). 
Kar Firtınası. Puşkin'den tercüme (The Blizzard. Translation from Pushkin), trans. by Gülnar Olga Dölebedeff (Istanbul: Alem Matbaası, 1307 [1891]).

Karadăg, Ayşe, B., 'The Traces of 'Feminity' of Woman Translators from the Tanzimat to the Second Constitution in Our Translated Literary History', Humanitas International Journal of Social Sciences, 2, (2013), 105-126.

Karimullin, Abrar G. 'O. S. Lebedeva - Gülnar khanum', Narody Aquii i Afriki (Peoples of Asia and Africa), 3 (1977), 146-152.

Kononov, A. N., 'Olga S. Lebedeva', Biobibliographicheskij slovar otechestvennih turkologov (Biobibliographical Dictionary of Native Turkologists), ed. by Andrei N. Kononov (Moscow: GRVL, 1974), pp. 204-205.

Lebedeff, Gülnar, Şair Puşkin (The Poet Pushkin), (Istanbul: Tercüman-1 Hakikat Matbaas1, 1308 [1891]).

Lebedeva, Gülnar, Rus Edebiyatı (Russian Literature), (Istanbul: Asadoryan Matbaas1, 1311 [1895]).

Lermontof'un Iblisi, [Lermontov's Demon], trans. by Olga de Lebedeff (Istanbul: Tercüman-1 Hakikat Matbaas1, 1308 [1891]).

Midhat, Ahmet Efendi, Faz̧l ve Feylesof Kızım. Fatma Aliye'ye Mektuplar (My Spiritual And Philosopher Daughter. Letters to Fatma Aliye), prep. for public. by F. S. Inceoğlu, Z. S. Berktaş (Istanbul: Klasik Yayınlar, 2011).

Mithat, Ahmet Efendi, Avrupa'da Bir Cevelan (Tour of Europe), translit. of Ottoman Turkish by Pala Arzu, reprint (Istanbul: Dergah Yayınları, 2015). 
71 OlCAY - Olga LEBEDEVA (MADAmE GÜlnAR): A Russian ORIETANTLIST AND TRANSLATOR ENCHANTS THE OTTOMANS

Okay, Orhan, Batı Medeniyeti Karşısında Ahmet Midhat Efendi (Ahmet Midhat Efendi in the Face of Western Civilization), (Istanbul: MEB, 1975).

Tolstoy, Count, Familiya saadeti (Family Happiness), trans. by Madame Gülnar (Istanbul: Tercüman-1 Hakikat Matbaas1, 1310 [1893]).

Shifman, Alexander, I., Lev Tolstoy i vostok (Leo Tolstoy and the East), 2 edn. (Moscow: Nauka, 1971).

Ves Peterburg na 1902: adresnaya I spravochnaya kniga g. S.-Peterburga (All Petersburg: Address and Reference Book of St Petersburg for 1902), (St Petersburg: A. S. Suvorin, 1902).

Yazgıç, Kamil, Ahmet Mithat Efendi: Hayatı ve Hatıraları (Ahmet Mithat Efendi: His Life and Memoirs), (Istanbul: Tan Matbaas1, 1940).

This work is licensed under the Creative Commons Attribution-No Derivatives 4.0 International License. To view a copy of this license, visit http:// creativecommons.org/licenses/by-nd/4.0/ or send a letter to Creative Commons, PO Box 1866, Mountain View, CA 94042, USA. 